\title{
Procalcitonin -A Reliable Marker for Diagnosis of Neonatal Sepsis in Compare to CRP
}

\author{
JESMIN AKTER ${ }^{1}$, FORRUKHAHAMMAD ${ }^{2}$, TAHMINABEGUM ${ }^{3}$
}

\begin{abstract}
Background: Early recognition and diagnosis of neonatal sepsis are difficult because of the variable and non-specific clinical presentation of this condition. It is extremely important to make an early diagnosis of neonatal sepsis for prompt institution of antimicrobial therapy. So the objective of the study was to evaluate the efficacy of serum procalcitonin as a reliable marker in diagnosis of neonatal sepsis.

Methodology: This cross sectional analytical study was carried out in the Special Care Baby Unit of a tertiary level care hospital in Bangladesh from September 2012 to May 2013. Total 75 newborn with suspected sepsis were included in the study. Specimens of blood were obtained from each neonate prior to commencement of antibiotic for sepsis work up. Serum CRP and procalcitoninlevels were measured. The data from blood cultures were used as the gold standard to evaluate the optimum sensitivity, specificity, positive predictive value (PPV), negative predictive value (NPV) and area under the Receiver Operative Characteristic (ROC) curves.
\end{abstract}

Results:Among total 75 newborns included in this study, 49.3\% (37) newborn were diagnosed as proven sepsis and $50.7 \%$ (38) newborn as clinical sepsis. The procalcitonin (PCT) was high in $58.7 \%(500-<2000 \mathrm{pg} / \mathrm{ml})$ newborn and remarkably high $(2000-<10000)$ in $36 \%$ newborn with sepsis. At a cut-off value $>500 \mathrm{pg} / \mathrm{ml}$, the sensitivity of PCT in detecting sepsis was $48.6 \%$, its specificity $76.3 \%$, positive predictive value was $66.7 \%$, and negative predictive value was $60.4 \%$ whereas the sensitivity of CRP for predicting sepsis was $35.1 \%$, specificity $78.9 \%$, positive predictive value $61.9 \%$ and negative predictive value was $55.6 \%$. The area under the ROC curve for procalcitonin(0.653) was significantly higher than CRP (0.571).

Conclusion:Serum PCT was superior to serum CRP level in terms of early diagnosis of neonatal sepsis, in detecting the severity of sepsis. PCT is a reliable marker than $C R P$ in the diagnosis of neonatal sepsis.

Key words: Sepsis, Procalcitonin, CRP

\section{Introduction}

Neonatal sepsis is the commonest cause of neonatal mortality and it is responsible for $30-50 \%$ of the total neonatal death in developing countries. ${ }^{1,2}$ It is estimated that $20 \%$ of all neonates develops sepsis and approximately $1 \%$ die of sepsis related causes .

1. Assistant Professor (Neonatology), Sir Salimullah Medical College and Mitford Hospital, Dhaka

2. Assistant Professor (Neonatology), Khulna Medical College, Khulna

3. Ex-Professor of Paediatrics, BIRDEM General Hospital, Dhaka Correspondence: Dr. Jesmin Akter, Assistant professor (Neonatology), Sir Salimullah Medical College and Mitford Hospital, Mobile 01552303450, E-mail: doctor.jesmin@gmail.com,

Received: 27 August 2017
Neonatal septicemia is a clinical syndrome of systemic illness accompanied by bacterium occurring in the $1^{\text {st }}$ 28 days of life. ${ }^{3}$ Neonatal sepsis may be categorized as early onset and late onset sepsis. Eighty five percent of newborns with early onset infection present within 24 hours and smaller percentage of patients present between 48 hours and 6 days of life. ${ }^{4}$

Sometimes infection in neonates is difficult to identify solely on the basis of physical finding, because signs are not specific and may be absent when the infection is identified just before delivary. ${ }^{5}$ Definitive diagnosis of neonatal sepsis is based on blood culture which take at least 48-72 
hours and yields a positive result in only 10$60 \%$ of cases. $^{6}$ It is also possible that a pseudonegative result may be obtained in some cases. ${ }^{7}$ In addition to the blood culture, other tests that are usually used for the diagnosis of neonatal sepsis include estimations of the white blood cell count, the absolute neutrophil count (ANC), micro ESR and I/T ratio. Unfortunately, these tests do not have a high sensitivity and specificity in diagnosing neonatal sepsis. ${ }^{8}$

C-reactive protein (CRP) is a good marker for diagnosis of neonatal sepsis. CRP is the most extensively used and investigated acute phase reactant. 9,10,11 and synthesized by the liver. It can be considered as a specific but late marker of neonatal infection .${ }^{12} \mathrm{CRP}$ level rises $12-24$ hours of infection and remain elevated for 3-7 days. Elevated CRP levels are seen in infection, in autoimmune disease, in surgery, meconium aspiration syndromeand recent vaccination. ${ }^{13,14}$

Several serum biomarkers have been identified in recent years with potential uses to help diagnose local and systemic infections; differentiate bacterial from viral or fungal infections and guide antibiotic therapy. The serum biomarker that has been most extensively studied recently is procalcitonin. ${ }^{15,16}$ Procalcitonin (PCT), a precursor of calcitonin is a 116 amino acid protein secreted by the $\mathrm{C}$ cells of thyroid gland in normal situation but its levels may increase during septicemia, meningitis, pneumonia and urinary tract infection. Macrophage and monocyte cells of various organs such as the liver, lungs, kidney, adipocytes and muscle cells are the potential sources of procalcitonin in severe bacterial infection . ${ }^{17,18}$ Serum procalcitonin levels appeared to correlate with the severity of microbial invasion. ${ }^{18}$ The increase level of procalcitonin (PCT) has been observed before the rise in CRP. ${ }^{19}$ The unique feature that PCT increase in bacterial and fungal infections but remain unchanged even in severe viral infections and other inflammatory diseases, make PCT attractive as a potential diagnostic variable for the diagnosis of bacterial infection. ${ }^{20}$ The measurement of procalcitonin is reliable and so can be used for early and rapid diagnosis of systemic infection in neonates in a short period of time.So the objective of the study to evaluate the efficacy of serum procalcitonin as a reliable marker for diagnosis of neonatal sepsis.

\section{Materials and Methods}

A prospective cross-sectional study was conducted at Special Care Baby Unit (SCABU) BIRDEM from Sept 2012 to May 2013. Total 75 cases were taken as consecutive sampling. The inclusion criteria were neonate who admitted into SCABU with clinical signs and symptoms of sepsis or who had maternal risk factors such as prolonged labour, PROM $>18$ hour, maternal fever, urinary tract infection, chorioamnionitis and neonatal risk factors such as prematurity, low birth weight. The exclusion criteria were neonates with congenital malformation, severe jaundice due to blood group incompatibilities, antibiotic therapy prior to admission. The study was approved by the ethical review committee of BIRDEM and informed parental consent was obtained prior to the enrollment in the study. Before initiation of antibiotic therapy, blood sample was taken for total leucocyte count, absolute neutrophil count, blood culture, CRP and serum procalcitonin. The newborns under study were classified into two groups - group I as proven sepsis (who had clinical sign and symptom and positive blood culture) and group II clinical sepsis (who had clinical sign and symptom of sepsis but negative blood culture). Normal serum level of PCT are less than procalcitonin $500 \mathrm{pg} / \mathrm{ml}$, test result interpretation is procalcitonin $<500 \mathrm{pg} / \mathrm{ml}$ - normal, $500-<2000 \mathrm{pg} / \mathrm{ml}$ progress to sepsis, $2000-<10000 \mathrm{pg} / \mathrm{ml}-$ sepsis and $>10000$ septic shock. PCT level is compared between the categories of infection.

\section{Statistical Analysis}

Data analysis was performed by using SPSS for windows version 15. Chi-square test, Mann- Whitney $U$ test and Validity test was done to measure the level of significance. Area under the ROC (Receiver operating characteristics) was evaluated. A $p$ value $\leq 0.05$ was considered level of significance.

\section{Results}

The study included a total 101 newborns who met the inclusion criteria. Of which 15 were excluded because of incomplete data such as missing blood C/S,PCT and CRP report and 12 patient died. Therefore 75 newborn were included in the final statistical analysis. The study subject divided into two group- proven sepsis group and clinical sepsis group. 50.7\% newborn were diagnosed as clinical sepsis and $49.3 \%$ as proven sepsis ( fig-1). In proven sepsis group, bacterial growth was found in $21.3 \%$, fungal growth in $28 \%$ and no 
growth observed in $50.7 \%$ newborn with sepsis (Figure 2). Among the bacterial growth, commonest organism was acinobactor (12\%) followed by klebsiella( $8 \%)$, pseudomonas( $1 \%$ ) and $28 \%$ new born had fungal growth(fig-3). The serum level of procalcitonin was high(500-d" $2000 \mathrm{pg} / \mathrm{ml}$ ) in $58.7 \%$ newborn with sepsis and remarkably high(2000-d" $10000 \mathrm{pg} / \mathrm{ml}$ ) in $36 \%$ newborn with sepsis and only $5.3 \%$ new born had normal procalcitonin level(Table-I). There was no significant difference of mean WBC count, ANC platelet count and CRPbetween two group of patients and only mean of procalcitonin was significantly high in proven sepsis group $\mathrm{p}-0.023$ (Table-II). The raised procalcitonin was observed in $48.6 \%$ new born with proven sepsis and $23.7 \%$ new born with clinical sepsis and it was statistically significant between two groups of newborn. On the other hand, raised CRP observed in $35.1 \%$ new born with proven sepsis and $21.1 \%(8)$ new born with clinical sepsis and it was not statistically significant in two groups(Table-III). The sensitivity of PCT in predicting sepsis was $48.6 \%$, its specificity was $76.3 \%$, positive predictive value(PPV) was $66.7 \%$ and negative predictive value(NPV) $60.4 \%$. The sensitivity of CRP in predicting sepsis was $35.1 \%$, its specificity was $78.9 \%$. its positive predictive was $61.9 \%$ and negative predictive value was $55.6 \%$. The sensitivity, PPV, NPV were higher for procalcitonin whereas specificity was lower in comparison to CRP (Table IV). Receiver operating characteristic(ROC) curves of procalcitonin and CRP was made according to the sensitivity and specificity of procalcitonin and CRP values using data from all study subject showed on Fig-4. The area under ROC curve for procalcitonin(median: $0.653,95 \%$ confidence interval Cl: 0528 to 0.778$)$ was significantly more $(0.653)$ than CRP(median: $0.571,95 \% \mathrm{Cl}: 0.441$ to 0528 ) on the ROC curve, $p$ value 0.023 which was significant (Table-V).

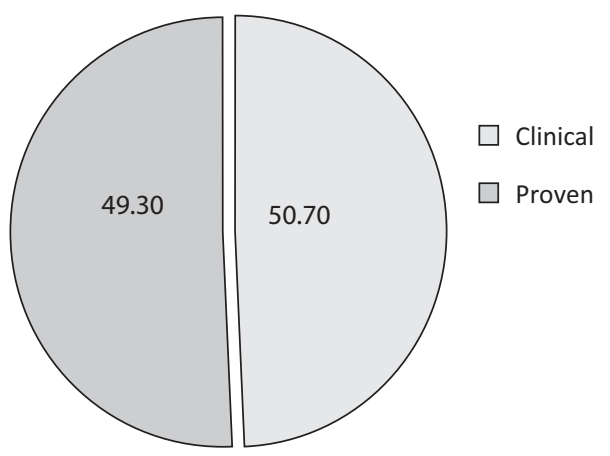

Fig.-1: Distribution of neonates according to the type of sepsis.

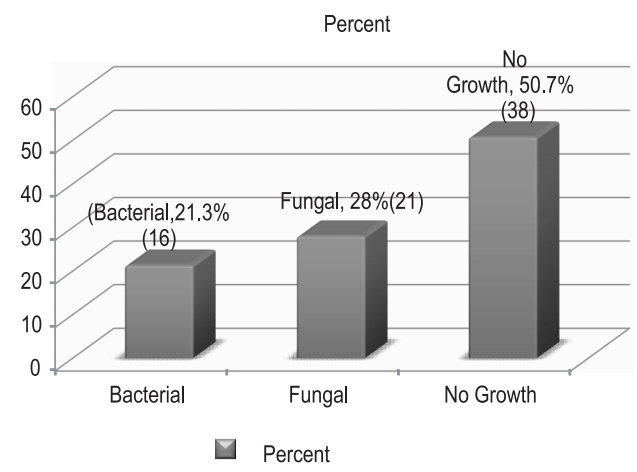

Fig.-2:Distribution of microbial growth pattern in newborn with sepsis

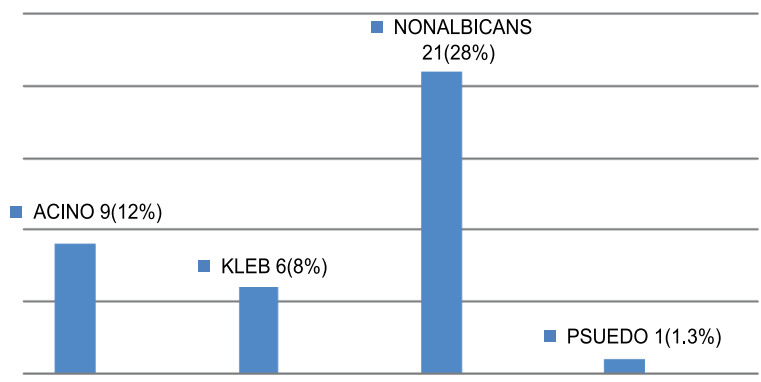

Fig.-3: Distribution of organism pattern in proven sepsis.

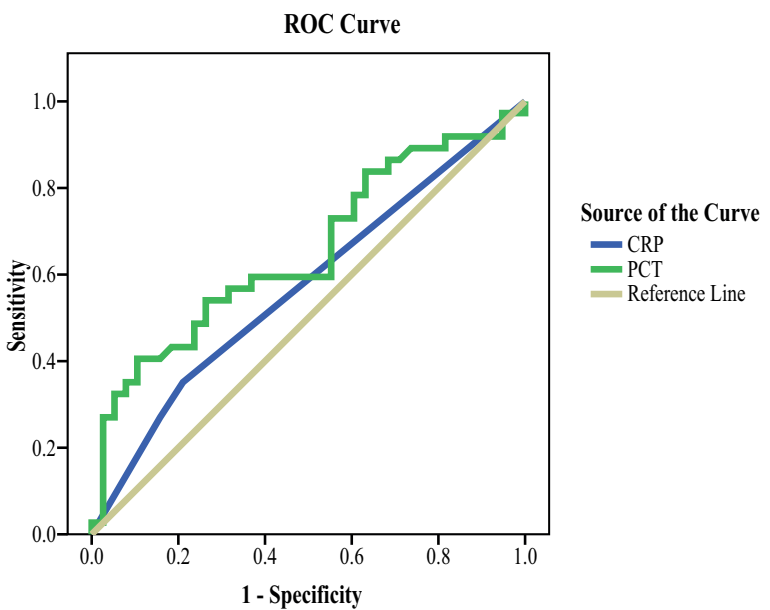

Fig.-4: Receiver operating characteristics (ROC) curves of procalcitonin and CRP was made according to the sensitivity and specificity of procalcitonin and CRP values using the data from all study subjects.

Table I

Distribution of procalcitonin level in newborn with sepsis

\begin{tabular}{lcc}
\hline Procalcitonin cat & Frequency & Percent \\
\hline Normal $(<500 \mathrm{pg} / \mathrm{ml})$ & 4 & $5.3 \%$ \\
Progress to sepsis & 44 & $58.7 \%$ \\
$(500-<2000 \mathrm{pg} / \mathrm{ml})$ & & \\
Sepsis $(2000-<10000 \mathrm{pg} / \mathrm{ml})$ & 27 & $36.0 \%$ \\
\hline Total & 75 & $100.0 \%$ \\
\hline
\end{tabular}


Table II

Comparision of mean of WBC count, ANC count, platelet count, CRP and procalcitonin in proven sepsis and clinical sepsis group

\begin{tabular}{lccc}
\hline & Pro3ven Sepsis & Clinical Sepsis & \\
& $\mathrm{n}=37$, mean \pm SD & $\mathrm{n}=38$, mean \pm SD & P value \\
\hline WBC count & $15880.14 \pm 13986.30$ & $13952.95 \pm 9160.11$ & 0.874 \\
Absolute & $6980.24 \pm 5460.92$ & $6675.24 \pm 4706.64$ & 0.853 \\
neutrophil count & & & \\
Platelet count & $123786.49 \pm 96747.07$ & $162307.89 \pm 90971.67$ & 0.057 \\
CRP & $11.35 \pm 7.97$ & $9.16 \pm 6.65$ & $0.177^{*}$ \\
PCT & $2451.00 \pm 1938.95$ & $1529.55 \pm 1168.37$ & $0.023^{*}$ \\
\hline
\end{tabular}

*Mann-Whitney $U$ test

Table III

Distribution of raised CRP and PCT in clinical sepsis and proven sepsis

\begin{tabular}{|c|c|c|c|c|}
\hline & \multicolumn{2}{|c|}{ Proven } & \multirow{3}{*}{$\begin{array}{l}\text { Clinical } \\
\mathrm{n}=75(\%)\end{array}$} & \multirow[t]{3}{*}{ Pvalue* } \\
\hline & Sepsis & SepsisTotal & & \\
\hline & $\mathrm{n}=37(\%)$ & $\mathrm{n}=38(\%)$ & & \\
\hline CRP-Raised & $13(35.1)$ & $8(21.1)$ & $21(28.0)$ & 0.174 \\
\hline PCT-Raised & $18(48.6)$ & $9(23.7)$ & $27(36.0)$ & 0.024 \\
\hline
\end{tabular}

${ }^{*}$ Chi-Square test was done

CRP- raised $>6 \mathrm{mg} / \mathrm{L}$

PCT- raised $>500 \mathrm{pg} / \mathrm{ml}$

Table IV

Comparision of validity tests of procalcitonin $(\mathrm{pg} / \mathrm{ml})$ and $C R P(\mathrm{mg} / \mathrm{L})$ in sepsis

\begin{tabular}{lcc}
\hline Validity tests & CRP & PCT \\
\hline Sensitivity & $35.1 \%(23.6-45.2)$ & $48.6 \%(36.3-59.1)$ \\
Specificity & $78.9 \%(67.7-88.7)$ & $76.3 \%(64.3-86.5)$ \\
PPV & $61.9 \%(41.6-79.6)$ & $66.7 \%(49.7-81.0)$ \\
NPV & $55.6 \%(47.6-62.4)$ & $60.4 \%(50.9-68.5)$ \\
Accuracy & $57.3 \%(45.9-67.2)$ & $62.7 \%(50.5-73.0)$ \\
\hline
\end{tabular}

Table V

Area under curve

\begin{tabular}{lcccc}
\hline Test Result Variable(s) & AUC & $\mathrm{p}$ & \multicolumn{2}{c}{$95 \%$ Confidence Interval } \\
\cline { 4 - 5 } & & value & Upper Bound & Lower Bound \\
\hline CRP & 0.571 & 0.289 & 0.441 & 0.701 \\
PCT & 0.653 & 0.023 & 0.528 & 0.778 \\
\hline
\end{tabular}

AUC (area under curve)

Null hypothesis: true area $=0.5$. 
The area under the ROC curve for procalcitonin (median: $0.653,95 \%$ confidence interval $\mathrm{Cl}: 0.528$ to 0.778 ) was significantly more (0.653) than CRP (median : $0.571,95 \% \mathrm{Cl}: 0.441$ to 0.528 ) on the ROC curve. Pvalue 0.023 which was significant.

\section{Discussion}

There is no single reliable test for the early definite diagnosis of neonatal sepsis. The C-reactive protein has been the most analyzed parameter for the detection of bacterial infections for many years ${ }^{22,26}$. Procalcitonin (PCT) has been proposed as a marker of bacterial sepsis.

In this present study,among 75 newborns, $49.3 \%$ (37)newborn were diagnosed as proven sepsis and $50.7 \%$ (38) newborn as clinical sepsis. Almost half of the newborn were diagnosed as culture proven sepsis due to early arrival in hospital, sample collection before giving antibiotic and proper aseptic technique in collection procedure. Bacterial growth was found in $21.3 \%$ newborn with sepsis. Commonest bacteria were acinetobacter (12\%) followed by klebsiella (8\%) and pseudomonas $(1 \%)$. This finding is similar with the study done by Sucilathangam et.al ${ }^{24}$ and Misra A et. $\mathrm{al}^{29}$ Begum S etal ${ }^{23}$. In our study, acinetobactor was the leading cause of neonatal sepsis and non albicans candida was isolated in $28 \%$ cases. As most of the newborn were exposed to broad-spectrum antibiotics, especially third generation cephalosporins, mechanical ventilation and not receiving enteral feeds were the risk factor for non-albicans candidal growth. ${ }^{22}$

In the present study, PCT was high $(500-<2000)$ in $58.7 \%$ newborn with sepsis and remarkably high (2000$<10000$ ) in $36 \%$ newborn with sepsis. Previous studies done by Chiesa $\mathrm{C}$ et al. ${ }^{30}$, Lapillonne $\mathrm{A}$ et al. ${ }^{31}$ and Monneret $G$ et al. ${ }^{33}$ had shown high PCT levels in neonates with proven or clinically diagnosed neonatal sepsis.

The comparison of mean of WBC count, ANC count, platelet count, CRP and procalcitonin in proven sepsis and clinical sepsis showed in table III. There was no significant difference of mean of WBC count, ANC count, platelet count and CRP in two groups patients but only mean of procalcitonin was significantly high in proven sepsis group and statistically significant, $p$ 0.02 . This finding was similar with Mohammed I A et al. study. 35

In our study, PCT was high in most newborn with proven sepsis (48.6\%) and in clinical sepsis $(23.7 \%)$ and it was statistically significant, $\mathrm{p}-0.024$ in two group of patients and this finding was similar with Carol et al. study, ${ }^{22}$ Koksel et al. ${ }^{36}$, Kawezynski et al. ${ }^{37}$ and Lopez Sastre et al. ${ }^{38}$ studies.

In the present study, the PCT levels were remarkably high in the neonates with proven sepsis $(48.6 \%)$ and also in clinical sepsis cases (35.1\%). This finding was comparable with that of the study which was conducted by YadollaZahadpasha et al. ${ }^{40}$ and Monneret et al..$^{33}$ There was a significant correlation between the serum PCT level and the proven sepsis ( $p-0.02)$ in our study which was comparable with Koksal et al. study. ${ }^{36}$

In the present study, the sensitivity of PCT for detecting sepsis (more than $500 \mathrm{pg} / \mathrm{ml}$ ) was $48.6 \%$, its specificity $76.3 \%$, its positive predictive value was $66.7 \%$ and negative predictive value was $60 \%$ and the sensitivity of CRP for predicting sepsis (more than $6 \mathrm{mg} / \mathrm{L}$ ) was $35.1 \%$, its specificity was $78.9 \%$, its positive predictive value was $61.9 \%$ and negative predictive value was $55.6 \%$. To evaluate the test performance ROC (receiver operating characteristic) curve using sensitivity and specificity of two test like PCT and CRP for cut off value of $>500 \mathrm{pg} / \mathrm{ml}$ and $>6 \mathrm{mg} / \mathrm{L}$ respectively. The area under the ROC for PCT (median: $0.653,95 \%$ confidence interval $\mathrm{Cl}: 0.528$ to $0.778)$ was significantly more $(0.653)$ than CRP (median: $0.571,95 \% \mathrm{Cl}: 0.441$ to 0.528 ), p value 0.023 which was significant. Such finding are similar with the study done by Hatherill et al. ${ }^{41}$, Sakha et al, ${ }^{42}$ Naher BS et al ${ }^{23}$ and Boo NY et al ${ }^{43}$ studies. The present study confirmed the findings of other investigators that PCT was more sensitive than CRP in the detection of neonatal sepsis, earlier as the PCT level rose than the CRP level during sepsis. Among the 75 cases, an elevated PCT was detected in 71 cases whereas an elevated CRP level was noticed only in 21 cases. In 37 culture positive cases, an elevated serum PCT level was noticed in 18 (48.6\%) cases whereas an elevated CRP level was noticed in only $13(35.1 \%)$ cases.

\section{Conclusion}

The findings of the present study suggest that the serum levels of PCT is a more reliable marker than the CRP or WBC counts in the early diagnosis of neonatal sepsis. As this study included a small group of population, we recommend further large scale, multi centered and follow up study to confirm the role of PCT in the diagnosis of neonatal sepsis. 


\section{References}

1. Bang AT, Bang RA, Bactule SB, Reddy HM, Deshmukh MD. Effect of home-based neonatal care and management of sepsis on neonatal mortality: field trial in rural India. Lancet 1999; 354:1955-61

2. Stoll BJ. The global impact of neonatal infection. Clinperinatol 1997; 24:1-21

3. Gotoff SP. Infection of the neonatal infant.In: Behrman RE; Kliegman RM, Jenson HB, eds. Nelson textbook of pediatrics. $16^{\text {th }}$ ed. Philadelphia: WB Saunders Company 2000; 543-49.

4. Gotoff SP, Behrman RE. Neonatal septicemia. J Pediatr 2005; 142-53

5. Blommendhal J, Janas M. Comparision of procalcitonin with CRP and white blood cell count for diagnosis of culture proven neonatal sepsis. Scand J Infect Dis 2002;34: $620-22$

6. Joram N, Bosch er C, Denizot S, V Loubersac, $\mathrm{N}$ winer, J C Roze et al. Umbilical cord blood procalcitonin and CRP concentrations as markers for early diagnosis of very early onset neonatal infection. Arch Dis Child Fetal Neonatal Ed 2006; 91: 65-6

7. Panero A, Pacifico L, Rossi N. Interleukin 6 in neonates with early and late onset infections. Paediatr infect Dis J 1997; 16:370-75.

8. Magudumana MO, Ballot DE, Cooper PA, Trusler J, Cory BJ, Viljoen E. et al. Serial interleukin 6 measurements in the early diagnosis of neonatal sepsis. J Trop paediatr 2000; 46: 267-71.

9. National Institute of population Research and Training (NIPORT), Mitra and Associates, and Macro International.2009. Bangladesh Demographic and Health Survey 2007. Dhaka , Bangladesh and Calverton,Maryland USA :National Institute Of Population Research and Training.136

10. National institute of Population Research and Training,Bangladesh Demographic and Health Survey 1996-1997.Dhaka,National Institute of Population Research and Training,1997.p.252

11. National Institute of Population Research and Training,Bangladesh Demographic and Health
Survey 1999-2000.Dhaka, national Institute of Population Research and Training,2001.p.280

12. Black S,Kushner I, Samols D. C-reactive protein. Minireview.JBlolChem 2004;279:48487-48490

13. Pierrakos C, Vincent JL. Sepsis biomarker. A review, Critical Care 2010; 14:R 15

14. Savitri K, Kate A, Gavin B, Edward A. Diagnostic and prognostic biomarkers of sepsis in critical care. J Antimicrob Che mother 2011; 66 Suppl 2:ii33-ii44

15. Marshall JC, Reinhart K. Biomarkers of Sepsis. Critical care Medicine 2009; 37(7) : 2209-8.

16. LuytCE,Combes A, Reynoud C, Cottalo G. Diagnostic value of simultaneous measurement of procalcitonin, interleukin-6 and CRP in prediction of Early onset neonatal sepsis. Mediterranean Journals of Hematology and infectious diseases. 2012; 4: 1

17. Gendrel D, Bohoun C. Procalcitonin as a marker of bacterial infection. Pediatr infect Dis J . 2000; 19 (8) :679-87 .

18. Eberhard Ok . Haubitz M, Brunkhorst FM, Laine S. Usefulness of procalcitonin for differentiation between activity of systemic autoimmune disease and invasive bacterial infection, Arthritis Rheum 1997 ; 40:1250-56

19. Whicher J, Bienvenu J, Monneret G. Procalcitonin as an acute phase marker. Ann Clin Biochem 2001;38:483-93.

20. Lindquist L, Linne $T$, Hanssons $L$. Value of cerebrospinal fluid analysis in the differential diagnosis of meningitis: a study of 710 patients with suspected central nervous system infection. Eur J clin Microbiol infect Dis. 1998; 7:374-380

21. Vergnano S, Menson E, Kennea N. Neonatal infection in England: the NeolN surveillance network. Arch Dis Child Fetal Neonatal Ed 2011; 96: F9-F14

22. Cloherty JP, Eichenwald EC, Stark AR. In: Manual of Neonatal care. $6^{\text {th }}$ Ed. Philadelphia : Lippincott Williams and Wilkings; 2008

23 Naher BS, Mannan MA, Noor K, Shahiddullah $M$. Role of procalcitonin and C-reactive protein in the diagnosis of neonatal sepsis. Bangladesh Med Res Counc Bull. 2011; 37(2):40-6. 
24. Sucilathangam G, Amuthavallik K, Velvizhi G, Ashiha begum M.A, Jeyamurugan T, Palaniappan N. Early diagnostic markers for neonatal sepsis: Comparing Procalcitonin and C-reactive protein. Journals of Clinical and Diagnostic Research. 2012;6(4): 627-631

25. Kafetzis DA, Tagani GS, Costalos C. Immunological markers in the neonatal period: their diagnostic value and accuracy in infection. Expert Rev MolDiagn 2005; 5:231-39.

26. Mannan Ma, Shahidullah M. In utility of C-reactive protein and heamatological parameters in the detection of neonatal sepsis. Bangladesh Journal of Child Health 2005;45:64-69.

27. Begum S, MA baki, GK Kundu, Islam I, Kumar M, Haque A. Bacterialogical Profile of Neonatal Sepsis in a Tertiary Hospital in Bangladesh. Journal of Bangladesh college of Physicians and Surgons 2012; 30:66-70.

28. Reghavan M, Mondal GP, Bhat BV. Perinatal risk factors in neonatal infections. Indian J Pediatr 1992;52:335-40.

29. Mishra A, Mishra S, Jaganath G. Acinatobacter Sepsis in Newborns. Indian Pediatrics 1998; 35:27-33.

30. Wemberg GA, Powell KR. Laboratory aids for the diagnosis of neonatal sepsis. In infectious disease of the fetus and newborn infant. Eds. Remington JS, Klein JO. Philadelphia, W B Saunders, $5^{\text {th }}$ ed 2001:1327-44.

31. Chiesa C, anero A, Rossi N, Reliability of procalcitonin concentrations for the diagnosis of sepsis in critically ill neonates. Clin Infect Dis. 1998; 26(3):664-72.

32. Lapillonne A, Baddon E, Monneret G, Franz AR, Henkel E. Lack of specificity of procalcitonin for sepsis diagnosis in premature infants. Lancet. 1998;351(9110):1211-2.
33. Monneret G, Labaune JM, Isaac C. Procalcitonin and $C$-reactive protein level in neonatal infections. Actapaeditr. 1997;86(2):209-12.

34. Carrol ED, Thomson AP, Hart CA. Procalcitonin as a marker of sepsis. Int J Antimicrobe Agents 2002; 86:282-85.

35. Mohammed IA, Maher Mohammed A W, Louai A S. Procalcitonin as a marker of neonatal of neonatal sepsis in intensive care units. Iran J Med Sci 2010; 35(3): 205-210

36. Koksal N, Harmanci R, Getinkaya M et al. Role of procalcitonin and CRP in diagnosis and follow up of neonatal sepsis. Turk J Pediatr. 2007; 49:21-9

37. Kawezymksi P, Piotrowski A. Procalcitonin and C-reactive protein as a marker of neonatal sepsis. Cinekol Pol.2004;75(6):439-44.

38. Lopez Sastre JB, Perez Solis D, Roques Serradilla V. Evalution of procalcitonin for diagnosis of neonatal sepsis of vertical transmission.BMC Pediatrics. 2007; 9.

39. Zahedpasha Y, AhmadpourKachol M, Hajiahmadi M, Mohsen Haghshenas. Procalcitonin as a marker of neonatal sepsis. Iran J Pediatr 2009; 19:117-122

40. Hatherill M, TibbySm, Sykes K,Meiser M. Diagnostic markers of infection; comparison of procalcitonin with $\mathrm{C}$-reactive protein and leucocyte count. Arch Dis Child 1999; 81: 417-21.

41. Sakha K, Husseini M.B, Seyyedsadri N. The role of procalcitonin in the diagnosis of neonatal sepsis and the correlation between procalcitonin and $\mathrm{C}$-reactive protein in these patients. Pak J BiolSci 2008; 11:1785-90.

42. Boo NY, Nor Azlina AA, Rohana J. Usefulness of a semi-quantitative procalcitonin test kit for the early diagnosis of neonatal sepsis. Singapore Med J 2008; 49:204-08. 